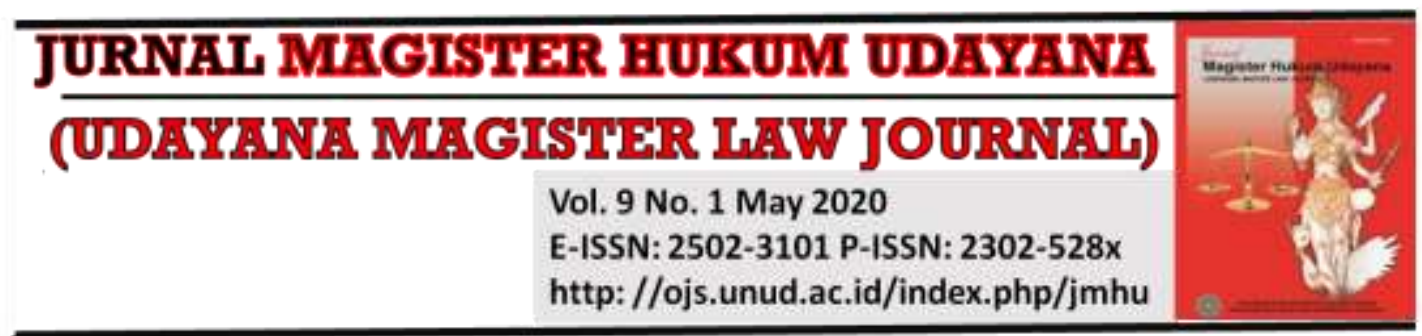

\title{
Law Enforcement and Justice: Perspective of Authority and Responsibility of the President towards the Judicial System
}

\author{
Zulkarnain Ridlwan', Ade Arif Firmansyah ${ }^{2}$ \\ ${ }^{1}$ Faculty of Law Lampung University, E-mail: zulkarnain.ridlwan@fh.unila.ac.id \\ ${ }^{2}$ Faculty of Law Lampung University, E-mail: ade.firmansyah@fh.unila.ac.id
}

Info Article
Received: $26^{\text {th }}$ August 2019
Accepted: $9^{\text {th }}$ March 2020
Published: $31^{\text {st }}$ May 2020
Keywords:
Law and Justice Enforcement;
President; Justice System
Corresponding Author:
Ade Arif Firmansyah, E-mail:
ade.firmansyah@fh.unila.ac.id
DOI:
10.24843/JMHU.2020.v09.i01.
p01

\section{Introduction}

The principle of sovereignty in Indonesia pledges the people as holders of sovereignty. The people's sovereignty is left to the 1945 Constitution of the Republic of Indonesia (hereinafter, Indonesian Constitution), to be shared. To divide it, the 1945 Constitution converts an abstract form of "sovereignty" into a more concrete form of "power". Then the sovereignty of the people at this point changes shape into state power. State power according to the doctrine must be divided into several parts, by the 1945 Constitution distributed to state institutions. For this reason, in every exercise of authority, state institutions that receive state power are exercising their respective portion of people's sovereignty.

\begin{abstract}
Andependent judicial power is very important as one of the be maintained in Indonesia. The purpose of this paper confirms that any attempt to intervene in the authority of the Supreme Court and the Constitutional Court in the justice system, including intervention from the President, must be considered an unconstitutional act and violates the ideals of the Indonesian rule of law. A review of the President's position in the statutory regulations found the fact that there was still a gap in the infiltration of the President's power over judicial authority. Specifically in two cases, the first relates to the ambivalence of the prosecutor's position that is not as firm as the Police. Second, the constitutional judge selection model. The need to re-arrange the mechanism for selecting constitutional judges derived from the President's proposal so that it can be more aligned with efforts to distance the President's power from the power of the judiciary. In addition to the recommendations to the formers to reorganize the wo potential infiltrations, this paper also recommends the itutionalization of public petitions based on Mark Tushnet's petition institution becomes a forum for gathering input and advice in law enforcement and justice. The opening of the President to accept public petitions makes it easier for the people to submit law enforcement issues which, in a sense of people's justice, must be addressed.
\end{abstract}


As is the practice in most countries, the distribution of state power in Indonesia is mainly contained in three branches; legislative, executive and judicial branches. The exercise of legislative power that makes laws accommodated by the House of Representatives, while the executive power that runs the law is led by the President, while the judicial power to enforce law and justice is carried out by the judiciary in Indonesia which is contained in the Supreme Court (Mahkamah Agung/MA) along with the judicial body under it, and the Constitutional Court (Mahkamah Konstitusi/MK).

Judicial power exercised by the Supreme Court and the Constitutional Court for Indonesia is a benchmark for law enforcement and justice. If the justice system is interpreted as a system of law enforcement and justice by the holder of the judicial power, then in the Supreme Court and the Court the system is actually running. It is hoped that from the two institutions the law can be enforced, which is formally carried out by examining, adjudicating, and deciding cases. ${ }^{1}$

The mention of law and justice in a series of definitions of the justice system above, is certainly not without purpose. The hope is that the Supreme Court and the Constitutional Court as court institutions will not only become "mouthpieces of law or mouthpieces of law", but also "mouths of justice". The result of course a justice system that brings law and justice together to meet the humanitarian demands of the Indonesian people.

In that straight line judicial power should be exercised. Also on that line judicial power should be maintained and guarded together by other branches of state power, also by the President. At the point of understanding of this limit, the Government's contribution is needed to participate in maintenance and safeguarding.

However, the role of the President in maintaining and maintaining judicial authority must be limited. Limits are intended to avoid the intervention of the President on judicial authority that should be independent. This needs to be emphasized because Indonesia has declared itself a state of law. A concept of a state characterized by a free and impartial trial. ${ }^{2}$

Violation of the boundaries so that the intervention of the President on judicial authority not only violates the concept of the rule of law in its universal doctrinal understanding, but can also be interpreted as a form of betrayal of the ideals of the rule of law after the amendment to the 1945 Constitution Republic of Indonesia. From the very beginning of the founding of the state, the founders of the state (in the Explanation of the 1945 Constitution) have outlined that the state formed is a state of law. A form of the rule of law is the opposite of a state based on power alone.

Based on the background above, the relevant issues to be answered in this paper are:

1. What is the position of independent judicial power in a theoretical study?

2. How does the President's position affect the justice system and law enforcement in Indonesia?

1 Compare with the definition of justice implied in Article 24 verse (1) UUD 1945 and Article 2 verse (1) and verse (2) UU 48/2009 tentang Kekuasaan Kehakiman.

2 See: Tim Penyusun, International Commision of Jurists, (1965). "The Dynamic Aspects of the Rule of Law in the Modern Age", Report on the Proceedings, the South-East Asian and Pacific Conference of Jurists, Bangkok-Thailand, February 15-19, h. 39-50. 
3. What regulatory ideas need to be stated in legislation so that the President's position in the Indonesian law state is more in line with law enforcement and justice efforts while supporting the justice system?

\section{Research Method}

This paper uses a conceptual approach and a law approach in elaborating on the problems raised. For that reason, in the first discussion, the conceptual study was conducted to explain the position of an independent judicial authority. Furthermore, elaborating a number of regulations related to the President's position which, according to the author, can influence the justice system and law enforcement in Indonesia. In the last discussion, the idea of improvement is proposed which can further support the role of the President in law and justice enforcement.

\section{Result and Discussion}

This paper will present a theoretical study of the President's position on the justice system (not 'in the justice system'). By taking the theory of the rule of law as a guideline, it is expected to be able to portray the alignment of the President's position on the judicial system in the applicable legislation. The rule of law's principle, which the authors mean specifically about judicial power that is free and impartial. The portrait will later show what the legislation must state so that the President's authority supports independence (freedom and impartiality) judicial power. An independent judicial power makes the judicial system reliable for law enforcement and justice.

As head of state and head of government, the position of the President in Indonesia is very important in law enforcement and justice. The position in the enforcement is done outside the justice system. "Outside the system" means not touching the authority of the judiciary in examining, adjudicating, and deciding cases. Such restrictions in the context of adhering to one of the main characteristics of the rule of law: the free and impartial judicial power. So in the same goal as the judiciary, the President upholds law and justice while maintaining the independence and impartiality of the Supreme Court and the Court. Because for the judiciary, partisans can only take the form of alignments to justice.

\subsection{Independence of Judicial Power as the Rule of Law}

The terminology of independence of judicial power (a term that represents freedom and impartiality of judicial power), and the rule of law, ${ }^{3}$ has a close connection. The relationship is illustrated by Burbank and Barry in the framework that the rule of law needs independent judicial power as a consequence of the adoption of the rule of law principle, while the independence of judicial power requires law as the highest state

3 The term 'negara hukum' The term 'rule of law' is translated from several foreign terms, including rechtsstaat and rute of law. However, the two concepts contained in the two terms are the same, namely to realize protection against the abuse of government power and protection of human rights. See: Tamanaha, Brian Z. (2011), On the Rule of Law, Cambridge: Cambridge University Press, p. 110. 
regulator. ${ }^{4}$ The interconnection between the two at the same time creates a causal relationship, that the independence of judicial power is the cause of the rule of law, on the other hand the judicial authority is a result of the implementation of the rule of law in a country.

The International Commission of Jurists at the South-East Asian and Pacific Conference of Jurists, 1965 in Bangkok agreed on a consensus on the characteristics of democratic governance under the Rule of Law, as follows: ${ }^{5}$

1. Constitutional protection, meaning that in addition to guaranteeing the rights of individuals, the constitution must also determine procedures for obtaining guaranteed protection of rights;

2. A free and impartial judiciary;

3. Free elections;

4. Freedom of expression;

5. Freedom of association / organization and opposition; and

6. Citizenship education.

Freedom and impartiality of the judiciary in carrying out its power is not only important for the judiciary itself, but also has a positive effect on the rule of law. It was stated this way, because judicial work directly supervised government actions. As stated John Alder "The judiciary accept responsibility for the maintenance of the rule of law that embraces a willingness to oversee executive action and to refuse to countenance behavior that threatens either basic human rights or the rule of law", 6 that the judiciary is responsible for maintaining the rule of law which also means monitoring government actions and refusing to approve behavior that threatens human rights or the rule of law.

Normatively in Indonesian laws and regulations, the provisions regarding judicial power are regulated in Article 24, Article 24A, and Article 24C of the 1945 Constitution, the details of which are specifically regulated in three laws, namely:

1. Law Number 4 of 2004 concerning Judicial Power;

2. Law Number 14 of 1985 concerning the Supreme Court, as amended by Law Number 5 of 2004; and

3. Act Number 24 of 2003 concerning the Constitutional Court, as amended by Act Number 8 of 2011.

The provisions in the 1945 Constitution and the three Laws regulate the main matters concerning judicial power including those related to the position of an independent judicial power which must be free from the influence of other branches of state power. ${ }^{7}$

4 Burbank, Stephen B. dan Friedman Barry, (2002). Judicial Independence at the Crossroads. An interdisciplinary Approach, California: Sage, p. 4-7.

5 International Commision of Jurists, 1965. "The Dynamic Aspects... Loc.Cit, sebagaimana dikutip pula dalam Suny, Ismail. (1987), Mekanisme Demokrasi Pancasila, Cetakan keenam, Jakarta: Aksara Baru, hlm. 14; dan Jasin, Johan. (2016). Hukum Tata Negara Suatu Pengantar, Jilid 2, Yogyakarta: Deepublish, h. 148.

6 Alder, John. (2002). General Principles of Constitutional and Administrative Law, Fourth Edition, New York: Palgrave Macmillan, p. 92.

7 Dari UUD 1945 dapat dilihat pada Pasal 24 ayat (1) diatur bahwa "Kekuasaan kehakiman merupakan kekuasaan yang merdeka untuk menyelenggarakan peradilan guna menegakkan hukum dan keadilan". This limitation confirms the nature of the administration of judicial authority, 
In theory, the implementing agency of judicial power most requires the existence of guarantees of independence from other branches of state power. The doctrine of separation of powers from American founding fathers, Alexander Hamilton mentioned that. A search for Hamilton's ideas in the 78th Federalist Paper states that there will be no independence as long as judicial power is not separated from the legislative and executive powers. ${ }^{8}$ While for the legislative and executive branches it is still possible to unite institutions or some personnel. ${ }^{9}$

Related to the separation, John Alder gives three meanings on the separation of powers, namely:10 separation of functions, separation of personnel, and checks and balances. Referring to the concept of separation of powers according to the meaning of John Alder, the separation of judicial power from the legislative and executive institutions includes personnel, functions, but is still covered by the principle of checks and balances.

Simply put, Howard and Carey offer two conditions that guarantee the independence of the judiciary, first, the independence of the executive and legislative branches; and second, free from corruption and bribery. ${ }^{11}$ These two conditions are needed in principle so that judicial power is free from parties who can influence decisions that are being and will be tried by judicial authority implementing institutions.

Bagir Manan argues that an independent judicial authority contains several basic objectives, namely: ${ }^{12}$ First, as part of a system of separation of powers or division of power between state governing bodies. Independent judicial power is needed to guarantee and protect individual freedom. Second, an independent judicial power is needed to prevent government officials from acting arbitrarily and oppressively. Third, an independent judicial power is needed to be able to assess the legal validity of government actions or statutory regulation, so that the legal system can be properly implemented and enforced.

Although the independence of judicial power is a condition reported in the rule of law, it does not negate the importance of accountability for its implementation. The judicial power exercised by the Supreme Court and the Constitutional Court in Indonesia is played by its judges who are inherent in human nature, that is, they can make mistakes and mistakes. So along with the need for judicial power to be given the freedom and kept away from the influence of partisanship, accountability for independence is also

which in exercising its authority to adjudicate is free from any influence so that law and justice can be upheld. On the verse (2) of the same article, stated the judicial institution that exercises judicial authority in Indonesia: "Kekuasaan kehakiman dilakukan oleh sebuah Mahkamah Agung dan badan peradilan yang berada di bawahnya dalam lingkungan peradilan umum, lingkungan peradilan agama, lingkungan peradilan militer, lingkungan peradilan tata usaha negara, dan oleh sebuah Mahkamah Konstitusi".

8 Madison, James and Alexander Hamilton, et.al., (1961). The Federalist Papers, New York: New American Library.

9 Allan, Trevor R.S. (2001). Constitutional Justice: A Liberal Theory of the Rule of Law, Oxford: Oxford University Press, p. 31.

10 Alder, John. (2015). Constitutional and Administrative Law, Tenth Edition, New York: Palgrave Macmillan,p. 138.

11 Howard, Richard M. dan Henry F. Carey. (2004). "Is an Independent Judiciary Necessary for Democracy?", Judicature Review Journal, 87 (6), p. 288.

12 Manan, Bagir. (1995), Kekuasaan Kehakiman Republik Indonesia, Bandung: Penerbitan Universitas-LPPM, UIB, h. 6. 
no less important. The importance of accountability is illustrated by Pamintel by stating: 13

Biases, outside pressures, conflicts of interest, and other self-dealing or selfinterested behaviors are all anathemas to the proper and ethical exercise of judicial powers. Here the focus is not on the decision itself being wrong-indeed, the judge's brother-in-law may well have deserved to win the case under the law anyway-but with the judges' improper reasons for rendering that decision. These expectations we have of judges are tied up in the concept of accountability.... Thus, while we will never find a consensus on what the right thing is, it may be easier to identify or envision scenarios of abuse of judicial authority that "cross the line". So while it is problematic to say that a judge should "do the right thing", it may be less so to assert that judge should "not do the wrong thing".

A simple form of applying the principle of accountability in the implementation of the most technical judicial power can be enforced on a judge's decision, which, according to Mochtar, must always be accessible to the public for transparency. ${ }^{14}$ The transparency of the judge's decision will make the parties concerned and affected by the decision to easily access it. With transparency, the parties can see the consideration that is used as a basis for judges to make decisions that should always be within the frame of law enforcement and bring about justice.

Thus it needs to be underlined, that the independence of judicial power in addition to being important as an element of the rule of law, should also be limited by having to comply with the principle of accountability. So along with its strict separation from other branches of state power and from outside influences of the justice system, the executor of judicial power, the Supreme Court and the Constitutional Court, must apply accountability to all actions of its institutions in enforcing law and justice.

\subsection{The President's Authority and Responsibility on the Judicial System}

According to Bagir Manan, authority in legal language is not the same as power (macht). Power only reflects the right to do or not do. In law, the authority also means rights and obligations (rechten en plichten). ${ }^{15}$ Philipus M. Hadjon stated that authority was obtained through three sources, namely: attribution, delegation, and mandate. The authority of attribution is usually outlined through the division of state power by the

13 Pimentel, David. (2015). "Reframing the Independence v. Accountability Debate: Defining Judicial Structure in Light of Judges' Courage and Integrity", Cleveland State Law Review, Vol. 51 (1), p. 13-14.

14 Mochtar, Zainal Arifin. (2014). “Sistem Peradilan yang Transparan dan Akuntabel (Catatan Kecil Penguatan), dalam Komisi Yudisial, Problematika Hukum dan Peradilan di Indonesia, Jakarta: Komisi Yudisial Republik Indonesia, h. 309.

15 Manan, Bagir. (2000), Wewenang Provinsi, Kabupaten dan Kota Dalam Rangka Otonomi Daerah. Makalah pada seminar nasional FH UNPAD, 13 mei. hlm. 1-2 dalam HR, Ridwan. (2006). Hukum Administrasi Negara. H. 102. 
constitution, the authority of the delegation and the mandate is the authority that comes from the delegation. ${ }^{16}$

The firmness of the statutory regulations in Indonesia in giving authority to the Supreme Court and the Constitutional Court as an institution that receives the people's sovereignty to hold judicial power has consequences in closing opportunities for other branches of power to take the portion of power in the justice system. Especially if the firmness is consistently combined with the implementation of the principle of independence of the judicial power as a whole.

As for the authority of the President, it is usually explicitly detailed in the Basic Law. This detail of authority is important to limit so that the President does not act arbitrarily. Some of the authority of the President which is usually formulated in various constitutions of a country, covers the scope of authority as follows: ${ }^{17}$

1. Authority that is executive or organizes government based on the constitution (to govern based on the constitution).

2. The Legislative authority or to regulate public or public interests (to regulate public affairs based on the law and the constitution).

3. Judicial authority in the context of restoring justice related to court decisions, namely to reduce penalties, provide forgiveness, or eliminate claims that are closely related to court authority.

4. Diplomatic authority, namely carrying out relations with other countries or other subjects of international law in the context of foreign relations, whether in a state of war or peace.

5. Administrative authority to appoint and dismiss people in state positions and state administrative positions.

Referring to the history of the institutionalization of judicial power in Indonesia, efforts to distance the President's power from the judiciary have been carried out with awareness after the fall of the New Order. This fact is noted in the MPR Stipulation on the Principles of Development Reform, as follows: ${ }^{18}$

During the thirty-two years of the New Order government, the development of law specifically concerning organic legislation regarding the limitation of the President's power was inadequate. This condition provides opportunities for corrupt, collusion and nepotism practices and culminates in deviations in the form of interpretations that are only in accordance with the tastes of the authorities. There has been an abuse of authority, legal harassment, neglect of a sense of justice, lack of protection and legal certainty for the community. The development of the judiciary by the executive is an opportunity for the authorities to intervene in the judicial process and the development of collusion and negative practices in the judicial process. Law enforcement has not provided a sense of justice and legal certainty in cases that confront the

${ }^{16}$ Hadjon, Philipus M. (1994). Fungsi Normatif Hukum Administrasi dalam Mewujudkan Pemerintahan yang Bersih, Disampaikan pada Pidato pengukuhan Guru besar di UNAIR 10 Oktober, h. 4.

17 Asshiddiqie, Jimly. (2005). Format Kelembagaan Negara dan Pergeseran Kekuasaan Dalam UUD 1945, FH UII Press, Yogyakarta, h. 75-77.

18 Ketetapan MPR RI Nomor X/MPR/1998 tentang Pokok-Pokok Reformasi Pembangunan dalam Rangka Penyelamatan dan Normalisasi Kehidupan Nasional Sebagai Haluan Negara. 
government or a strong party with the people, thus placing the people in a weak position.

The limitation of the President's power over intervention into the judiciary was only formulated straightforwardly in Law Number 48 of 2009 concerning Judicial Power. ${ }^{19}$ In the Elucidation of Article 3 paragraph (1) of Law 48/2009 it is stated: What is meant by "independence of the judiciary" is to be free from outside interference and free from all forms of pressure, both physical and psychological. The formulation requires a judicial system that is free from the interference of extra-judicial parties, except as stipulated in the 1945 Constitution of course.

The authority of the president is the attribution authority that is clearly outlined through the 1945 Constitution. The 1945 Constitution has given the President great authority, among which authority is related to judicial power and law enforcement and justice. The intended authority is:

1. Give pardons and rehabilitation with due regard to the Supreme Court's considerations (Article 14 Paragraph 1);

2. Give amnesty and abolition by taking into consideration the House of Representative (DPR) (Article 14 Paragraph 2).

3. Determine the Supreme Court Justices (at the recommendation of Judicial Commission (Komisi Yudisial/KY) and after the approval of the DPR, Article 24A Paragraph 3);

4. To appoint and dismiss KY members (with the approval of the DPR, Article 24B paragraph 3)

5. To stipulate nine constitutional justices (and propose three of them, Article 24C paragraph 3);

6. Protection, promotion, enforcement and fulfillment of human rights (Article 28I paragraph 4);

The articles above constitute the authority of the President relating to judicial power and law and justice enforcement. However, it must be noted, no such authority intervenes in the independence of judicial power, because all of them are outside the judicial system. More than that, it can be seen that the attribution of authority does not put the President in a single role, there are other state institutions that give consideration and/or approval. Unless it is related to the protection, promotion, enforcement and fulfillment of human rights, the President can do it independently as a representation of the state. The President can walk with the Attorney General and the Police in the context of law enforcement in the field of human rights.

According to the Prosecutor's Law (Law Number 16/2004), just like the Supreme Court and the Constitutional Court, the Prosecutor's Office was given independence in exercising its authority. The Prosecutors' Office was given the status of a government institution that exercises state power in the field of prosecution, independently. Therefore, the prosecutor's office should be free from the influence of government and other powers. ${ }^{20}$ However, the same law stipulates that the Attorney General's Office is

19 Actually the same provisions have been regulated in Law No. 14 of 1970 concerning the Basic Provisions for Judicial Power and Law No. 14 of 1985 concerning the Supreme Court. It's just that its implementation is not effective because the government often intervenes in the judicial process.

20 General Explanation of UU Nomor 16 Tahun 2004 tentang Kejaksaan Republik Indonesia. 
a government agency that exercises state power in the field of law enforcement by adhering to the laws and policies set by the government. ${ }^{21}$ The ambivalent attitude of the legislators who should be regulated more firmly.

Unlike the Police, the Police Law regulates the position of police institution firmly under the President. ${ }^{22}$ Therefore the National Police as an instrument of the state that plays a role in maintaining security and public order, upholding the law, as well as providing protection, shelter, and services to the public, should be able to function by the President to uphold the law and as much as possible participate in realizing justice.

The National Police chief is responsible to the President, while the Attorney General is responsible not only to the President but also to the DPR. To assist the President's task with regard to Polri's policy direction, a National Police Commission was formed. Meanwhile, the President is assisted by the Prosecutors' Commission to improve the quality of the Prosecutor's performance. Through these two Commissions, the President can determine the direction of the Police and Prosecutors' policies that can further ensure the rule of law and the realization of justice for the people of Indonesia. It should be emphasized that the President's authority over the Prosecutors' Office and the Police is only in the context of achieving the rule of law and the realization of justice within the rule of law state. Earlier than that, the President was responsible for selecting the right figures to hold the position of National Police Chief and Attorney General.

Back to the six Article of the 1945 Constitution which gave authority to the President above. Note that according to the author can influence the judicial power, namely the authority of the President in proposing three of the nine constitutional justices. Indeed, a deeper study is needed to verify the author's assumption that the authority of the proposal is problematic. On the one hand, the distribution of 'rations' to three state institutions (MA, DPR, and President) for each entitled to propose constitutional judges are considered a form of checks and balances. But on the other hand, it is difficult not to assume the tendency of 'repayment' elected constitutional judges to those who have proposed his candidacy. Especially if the elected judge wants to be reelected.

It cannot be denied, the President (as well as the DPR) as the proponent of constitutional judges is very closely attached to political interests. Interests that also need to be prosecuted and fought up to the Constitutional Court's table. As understood, 4 (four) authorities and 1 (one) obligation of the Constitutional Court ${ }^{23}$ cannot be separated from the interests of the parties requesting the settlement of the case. The parties in question also include the President (with the government apparatus).

21 Ibid.

22 Pasal 8 UU Nomor 2 Tahun 2002 tentang Kepolisian Republik Indonesia.

234 MK's authority is regulated in UUD 1945 Pasal 24C ayat (1) Mahkamah Konstitusi berwenang mengadili pada tingkat pertama dan terakhir yang putusannya bersifat final untuk menguji undang-undang terhadap Undang-Undang Dasar, memutus sengketa kewenangan lembaga negara yang kewenangannya diberikan oleh Undang-Undang Dasar, memutus pembubaran partai politik, dan memutus perselisihan tentang hasil pemilihan umum. Pada ayat (2) pasal yang sama, diatur 1 kewajiban MK: Mahkamah Konstitusi wajib memberikan putusan atas pendapat Dewan Perwakilan Rakyat mengenai dugaan pelanggaran oleh Presiden dan/ atau Wakil Presiden menurut Undang-Undang Dasar. 
To avoid the possibility of partiality of MK judges in return for their proposals, it is necessary to consider changing the mechanism for constitutional judge determination in the form of more open selection. The author proposes the idea of appointing a Joint Selection Committee between the Supreme Court, the Parliament and the President. When there is a constitutional justice position to be filled, a Joint Selection Committee is formed. The three state institutions can still submit proposals to constitutional judges, ${ }^{24}$ but the Joint Selection Committee further selects, including exploring the track record and public response. Certainly it still has the minimum requirements stipulated in Article 24C paragraph (5) of the 1945 Constitution which regulates: "Constitutional Justices must have integrity and personality that are not blameworthy, fair, statesmen who control the constitution and constitution, and do not double as state officials".

The mechanism for establishing constitutional judges through the Joint Selection Committee should be able to prevent judges elected from 'debt of gratitude' to the President. Elected judges also do not need to 'seek face' by advancing the interests of the President in adjudicating case requests at the Constitutional Court in order to be reelected as constitutional justices.

\subsection{The President's Authority in Law Enforcement and Justice in Indonesia}

Unlike restrictions on the strict judicial system, the President's authority in law enforcement outside the justice system is more lenient. With his great power, and the highest command over the police and prosecutors, the President has a great responsibility to uphold law and justice, especially when it comes to the human rights of his citizens.

As mentioned earlier, one of the powers of law enforcement by the President is related to human rights. Full mention in the 1945 Constitution Article 28I paragraph (4) The protection, promotion, enforcement and fulfillment of human rights is the responsibility of the state, especially the government. Confirming that provision, in paragraph (5) the same article states: "To uphold and protect human rights in accordance with the principles of a democratic rule of law, the implementation of human rights is guaranteed, regulated, and outlined in legislation. Two main points which the author underlines from the two paragraphs of Article 28I, namely: state responsibility and the principle of democratic rule of law.

First, regarding state responsibility. the use of the 'responsibility' diction emphasizes that the protection, promotion, enforcement and fulfillment of human rights is not an authority, but a constitutional order to be carried out by the state with pressure on the government. So for the government, in this case commanded by the President, efforts to protect, promote, uphold, and fulfill human rights are not an option to be implemented or not, but a necessity.

Second, the principle of democratic rule of law. The Interesting thing in the formulation of Article 28I paragraph (5), the presence of the word 'democratic' attached to the term rule of law. Democratic means or according to the understanding of

24 So there is no need to make changes Article 24C verse (3) UUD 1945. 
democracy. ${ }^{25}$ Understanding democracy if it is associated with the rule of law can mean a people's government to oversee ideas that prioritize equal rights and obligations and equal treatment of citizens.

\subsection{Mark Tushnet's Idea and Institutional Options for Public Petitions}

Continuing the discussion of sub 2.3 above, within the limits of the understanding of Article 28I paragraph (4) of the 1945 Constitution, the author connects with the idea of constitutional law introduced by Mark Tushnet with the term populist constitutional law. Tushnet's idea places the public in a position that can actively contribute to selfgoverning, which in the context of law enforcement and justice can be interpreted by the public (joining with the President) to exercise authority and responsibility, including to protect, advance, uphold and fulfill human rights.

Based on this idea, it is necessary to set mechanisms and procedures for public participation in providing input as well as support to the President to enforce law and justice on certain issues that disturb the sense of public justice. The form of public involvement in law and justice enforcement aimed at the President can take the form of a public petition.

For the people of Indonesia, the right of petition is regulated in the 1945 Constitution concerning freedom of expression, and the position of citizens in law and government. More explicitly, the right of petition is contained in the Human Rights Act, that every person has the right to submit opinions, requests, complaints and or proposals to the government. ${ }^{26}$ So the guarantee of the right to participate in government has been given by the Indonesian constitution, continued with the guarantee as human rights in the Act.

It's just that the petition regulated in the Human Rights Act is still general for all issues that are considered important to the public. What is proposed in this paper is intended within the scope of law enforcement and justice, which according to the public based on statutory regulations, can be done by the President. The petition to the President will be a space for interaction with the people. Starting from the public petition, the President coordinates and communicates with state apparatus that is given the power of law enforcement and justice, through the prosecutors and the police for example.

The comparison study shows the position of the public petition which is quite central in a presidential system state. In the United States, specifically given the public space to participate in submitting proposals and input to the President, including in matters of law enforcement. The participation space was formally institutionalized and managed professionally through an online channel: https://petitions.whitehouse.gov/

25 As for democracy, it has two meanings, (1) a government in which all people participate in governing using their representatives; people's government; (2) ideas or views of life that prioritize equal rights and obligations and equal treatment for all citizens. Tim Penyusun, (2008). Kamus Bahasa Indonesia, Jakarta: Pusat Bahasa Departemen Pendidikan Nasional, h. 337.

26 Article 44 UU Nomor 39 Tahun 1999 tentang Hak Asasi Manusia, "Setiap orang baik sendiri maupun bersama-sama berhak mengajukan pendapat, permohonan, pengaduan, dan atau usulan kepada pemerintah dalam rangka pelaksanaan pemerintahan yang bersih, efektif, dan efisien, baik dengan lisan maupun dengan tulisan sesuai ketentuan peraturan perundang-undangan." 
The Philippine constitution regulates petition rights as one of the basic rights which cannot be restricted by the state, as stipulated in Article III, Section 4: 27 "No law shall be passed abridging the freedom of speech, of expression, or of the press, or the right of the people peaceably to assemble and petition the Government for redress of grievances. Even in the context of legislation, if the petition is signed by ten percent of the voters registered in the election data, the Philippine Congress must respond immediately. ${ }^{28}$ Briefly the petition in the Argentine Constitution is regulated in Section 14: 29 "All the inhabitants of the Nation are entitled to the following rights, in accordance with the laws that regulate their exercise, namely: ...; to petition the authorities; .. "These rules form the basis for all Argentine residents to petition the government in power. Although in this case the meaning of "authority" is not specified, it is known that the meaning is government.

\section{Conclusions}

Based on the discussion above, it can be concluded and suggested several things as follows:

Theoretically, the position of an independent judiciary is very important. As one of the main characteristics of the rule of law, the existence of an independent judicial power must be maintained in Indonesia. Every effort to intervene in the authority of the Supreme Court and the Court, including intervention from the President, in the justice system must be considered an unconstitutional act and violates the ideals of the Indonesian rule of law.

The regulation of the President's position in the legislation related to judicial power, apparently still leaves an infiltration gap for the President's power. The ambivalence in the regulation of the Prosecutor's Office that is not as firm as the Police, needs to be the attention of the legislators. Also, the rearrangement of the constitutional judge selection model should be considered so that it can be more aligned with efforts to distance the President's power from the power of the judiciary.

The President's openness to receiving input and advice in law enforcement and justice can be done by gathering public petitions. The opening of the President to accept public petitions makes it easy for the people to submit law enforcement issues that must be addressed. Issues that touch, and might interfere with, people's sense of

27 The Philippine constitution is the constitution after the last amendment in 1987, as officially translated on the page www.constituteproject.org (accessed 5 Juli 2019).

28 Lihat Article III Section 32 Konstitusi Filipina: "The Congress shall, as early as possible, provide for a system of initiative and referendum, and the exceptions therefrom, whereby the people can directly propose and enact laws or approve or reject any act or law or part thereof passed by the Congress or local legislative body after the registration of a petition therefor signed by at least ten per centum of the total number of registered voters, of which every legislative district must be represented by at least three per centum of the registered voters thereof". Article 6, section 22 Konstitusi Filipina. Lihat pula: IPU PARLINE database_PHILIPPINES (Kapulungan Ng Mga Kinatawan), Oversight., Lihat: www.archive.ipu.org/parline-e/reports/CtrlParlementaire /2253_F.htm diakses 5 Juli 2019.

29 Konstitusi Argentina yang dimaksud adalah konstitusi pasca amandemen terakhir Tahun 1994, sebagaimana diterjemahkan secara resmi dalam laman International Constitutional Law http://www.servat.unibe.ch/icl/ (diakses 5 Juli 2019). 
justice. for this reason, the institutionalization of public petitions through bodies under the President is an important option to consider.

\section{References}

$\underline{\text { Books }}$

Alder, John. (2015). Constitutional and Administrative Law, Tenth Edition. New York: Palgrave Macmillan.

Alder, John. (2002). General Principles of Constitutional and Administrative Law, Fourth Edition. New York: Palgrave Macmillan.

Allan, T. R. (2003). Constitutional justice: A liberal theory of the rule of law. Oxford University Press on Demand.

Asshiddiqie, Jimly. (2005), Format Kelembagaan Negara dan Pergeseran Kekuasaan Dalam UUD 1945, Yogyakarta: FH UII Press.

Burbank, Stephen B. dan Friedman Barry. (2002). Judicial Independence at the Crossroads. An interdisciplinary Approach. California: Sage.

Hadjon, P. M. (1994). Fungsi Normatif Hukum Administrasi dalam Mewujudkan Pemerintahan yang Bersih. Makalah disampaikan pada Orasi Guru Besar Ilmu Hukum, Fakultas Hukum Universitas Airlangga, Surabaya.

Howard, Richard M. dan Henry F. Carey. (2004). "Is an Independent Judiciary Necessary for Democracy?", Judicature Review Journal, 87 (6).

HR, Ridwan. (2006), Hukum Administrasi Negara. Jakarta: Raja Grafindo Persada.

Jasin, Johan. (2016). Hukum Tata Negara Suatu Pengantar, Jilid 2. Yogyakarta: Deepublish. Madison, James., et.al. (1961). The Federalist Papers. New York: New American Library.

Manan, Bagir. (1995). Kekuasaan Kehakiman Republik Indonesia. Bandung: Penerbitan Universitas-LPPM, UIB.

Mochtar, Zainal A. (2014). “Sistem Peradilan yang Transparan dan Akuntabel (Catatan Kecil Penguatan), dalam Komisi Yudisial, Problematika Hukum dan Peradilan di Indonesia. Jakarta: Komisi Yudisial Republik Indonesia.

Penyusun, Tim. (2008). Kamus Bahasa Indonesia. Jakarta: Pusat Bahasa Departemen Pendidikan Nasional.

Ridlwan, Z. (2019). Penegakan Hukum dan Keadilan: Perspektif Wewenang dan Tanggung Jawab Presiden terhadap Sistem Peradilan. Makalah FGD dengan Lembaga Pengkajian MPR RI.

Suny, Ismail. (1987). Mekanisme Demokrasi Pancasila, Cetakan keenam. Jakarta: Aksara Baru.

\section{Journal/Proceeding}

Manan, B. (2000). Wewenang Provinsi, KabuPaten, dan kota dalam rangka otonomi daerah. In Makalah Pada Seminar Nasional, Fakultas Hukum Unpad, Bandung (Vol. 13).

Pimentel, D. (2009). Reframing the Independence v. Accountability Debate: Defining Judicial Structure in Light of Judges' Courage and Integrity. Clev. St. L. Rev., 57, 1.

Tim Penyusun, Jurists International Commision, (1965). “The Dynamic Aspects of the Rule of Law in the Modern Age", Report on the Proceedings, the South-East Asian and Pacific Conference of Jurists, Bangkok-Thailand, February 15-19, 
Tamanaha, B. Z. (2011). The rule of law and legal pluralism in development. Hague Journal on the Rule of Law, 3(1), 1-17. https://doi.org/10.1017/S1876404511100019

\section{Website Content}

www.archive.ipu.org/parline-e/reports/CtrlParlementaire/2253_F.htm. accessed Juli 5, 2019. www.constituteproject.org. accessed Juli 5, 2019.

www.servat.unibe.ch/icl/. accessed Juli 5, 2019.

\section{Legislation}

Undang-Undang Dasar Negara Republik Indonesia Tahun 1945.

Konstitusi Filipina.

Konstitusi Argentina pasca amandemen terakhir Tahun 1994.

Undang-Undang Nomor 14 Tahun 1985 tentang Mahkamah Agung, sebagaimana telah diubah dengan Undang-Undang Nomor 5 Tahun 2004.

Undang-Undang Nomor 2 Tahun 2002 tentang Kepolisian Republik Indonesia.

Undang-Undang Nomor 24 Tahun 2003 tentang Mahkamah Konstitusi, sebagaimana telah diubah dengan Undang-Undang Nomor 8 Tahun 2011.

Undang-Undang Nomor 16 Tahun 2004 tentang Kejaksaan Republik Indonesia.

Undang-Undang Nomor 48 Tahun 2009 tentang Kekuasaan Kehakiman.

Ketetapan Majelis Permusyawaratan Rakyat Republik Indonesia Nomor X/MPR/1998 tentang Pokok-Pokok Reformasi Pembangunan dalam Rangka Penyelamatan dan Normalisasi Kehidupan Nasional Sebagai Haluan Negara. 